International Journal of Microbiology Research

ISSN: 0975-5276 \& E-ISSN: 0975-9174, Vol. 3, Issue 1, 2011, pp-48-55

Available online at http://www.bioinfo.in/contents.php?id=27

\title{
OENOCOCCUS OENI FROM PATAGONIAN RED WINES: ISOLATION, CHARACTERIZATION AND TECHNOLOGICAL PROPERTIES
}

\author{
BRAVO-FERRADA B.M. ${ }^{1}$, DELFEDERICO L. ${ }^{1}$, HOLLMANN A. ${ }^{1}$, VALDÉS LA HENS D. ${ }^{1}$, \\ CURILÉN Y. ${ }^{2,4}$, CABALLERO A. ${ }^{2,3,4}$, SEMORILE L. ${ }^{*}$. \\ 'Laboratorio de Microbiología Molecular, Departamento de Ciencia y Tecnología, Universidad Nacional de \\ Quilmes, Roque Sáenz Peña 352, (B1876BXD) Bernal, Buenos Aires, Argentina. \\ ${ }^{2}$ Facultad de Ciencia y Tecnología de los Alimentos, Universidad Nacional del Comahue, 25 de Mayo y \\ Reconquista, (8336) Villa Regina, Río Negro, Argentina. \\ 3Facultad de Ingeniería, Universidad Nacional del Comahue, Buenos Aires 1400, (8300) Neuquén, Argentina. \\ 4IDEPA CONICET-Universidad Nacional del Comahue, Buenos Aires 1400, (8300) Neuquén, Argentina. \\ *Corresponding Author: Email- Isemorile@unq.edu.ar
}

Received: November 05, 2010; Accepted: March 09, 2011

\begin{abstract}
Pinot noir vinifications carried out at industrial scale during 2008 vintage were monitored in Patagonian region, Argentina, and several lactic acid bacteria were obtained. By analysis of a fragment of rpoB gene, speciesspecific PCR of malolactic enzyme and sequencing of $16 \mathrm{~S}$ rRNA gene, three isolates were identified as Oenococcus oeni. Polyphasic typing made by carbohydrate fermentation behaviour and RAPD-PCR grouped the isolates and 0 . oeni reference strain in three different clusters. Additionally, the effect of ethanol on bacterial growth and malolactic activity was evaluated. In spite of some inhibitory effects were found, the three isolates were able to growth in all ethanol concentration tested. A clear correlation was found between the different clusters obtained and their ethanol tolerance. All indigenous 0 . oeni showed a strong malolactic activity at all ethanol concentrations assayed, indicating that this alcohol just affect the growing parameters of bacteria, but not the malolactic activity. These promissory results suggest a potential enological application of the 0 . oeni indigenous isolates as malolactic fermentation starters in winemaking.
\end{abstract}

Keywords- Pinot noir wine, Argentinean North Patagonia, malolactic fermentation, Oenococcus oeni

\section{Introduction}

The malolactic fermentation (MLF), i.e. the conversion of L-malic to L-lactic acid and carbon dioxide, is the biochemical process by which lactic acid bacteria (LAB) contribute to the wine deacification [1]. Additionally, MLF has important influences on wine flavour and improves its microbiological stability [1, 2]. MLF often occurs spontaneously after alcoholic fermentation (AF) and Oenococcus oeni is the main species among bacteria responsible for this process [3]. The MLF becomes especially relevant in red wines with low $\mathrm{pH}$ as those from cold regions and from early Vitis vinifera $L$ varieties, i.e. Pinot noir, where $L$-malic acid can reach high concentrations. Spontaneous MLF is not always guaranteed and, when it occurs, its evolution is difficult to predict [4]. Many studies have focused on the stimulation of MLF by selected bacterial strains and recent winery practices consist in using malolactic starters for direct inoculation in wines [3, 5]. However, use of commercial starter strains is not always effective [5]. Nowadays, selection of strains for wine inoculation is performed by classic tests based on the survival on wine conditions and monitoring the consumption of L-malic acid. O. oeni strains are well-known for their phenotypic variations in terms of tolerance of harsh wine conditions and malolactic activity [1] which correlates with a high level of allelic diversity between strains [6-8].

Located at $37^{\circ} 5^{\prime}$ and $40^{\circ} 5^{\prime}$ Southern latitude, Argentinean North Patagonia is one of the most Southern winegrowing region of the world. This region has optimal agro-ecological conditions for high quality viticulture and a long winemaking tradition [9]. Both spontaneous and guided alcoholic fermentations are carried out and young dry red from neutral Vitis vinifera varieties are mostly produced [10]. However, the use of starters to guide MLF is not a routine practice in Patagonian red wine vinifications where this process is carried out spontaneously.

The aim of this work was to seek out 0 . oeni isolates from a Patagonian $\mathrm{LAB}$ collection obtained from Pinot noir wines and to characterize some of their genomic, metabolic and technological features for their potential use as malolactic starters. 


\section{Materials and Methods} a) Reference strains

The reference strains used in this study were Lactobacillus mali ATCC 27304, Lactobacillus plantarum ATCC 14917, Leuconostoc mesenteroides subsp. mesenteroides ATCC 23386, Oenococcus oeni ATCC 27310 and Pediococcus parvulus ATCC 19371

\section{b) Wine samples}

Pinot noir wine samples were collected from a cellar located in the High Valley of the Río Negro, Argentine Patagonia, during 2008 vintage. Alcoholic fermentations (AF), were carried out spontaneously (natural fermentation, NF) or by grape inoculation with S. cerevisiae F15 (Laffort SA, Bordeaux, France) commercial starter (guided fermentation, GF) at $25 \pm 2{ }^{\circ} \mathrm{C}$ until dryness (total reducing sugars $\cong 2 \mathrm{~g} / \mathrm{L}$ ). Wine samples were taken aseptically at 6, 24 and 50 days after AF was completed.

\section{c) $L A B$ isolation}

Samples enrichment was done in Mann-.RogosaSharpe (MRS) broth supplemented with 15\% tomato juice (MRS-TJ) pH 4.8, containing $100 \mathrm{mg} / \mathrm{L}$ of cycloheximide to suppress yeast growth. Cultures were grown at $28{ }^{\circ} \mathrm{C}$ under microaerophilic conditions for 10 days. Samples were taken at 0, 5 and 10 days and they were spread onto MRS-TJ agar and incubated under microaerophilic conditions for 10 days at $28{ }^{\circ} \mathrm{C}$. Colonies with different morphology were recovered. $L A B$ were initially characterized by Gram staining and catalase activity. Bacterial isolates were sub-cultured on the same medium until purification. Pure LAB cultures were maintained in MRS broth with $30 \%$ glycerol at $-20^{\circ} \mathrm{C}$ and $-80^{\circ} \mathrm{C}$.

\section{d) DNA extraction}

Genomic DNA was obtained from $L A B$ isolates and reference strains. Briefly, cells were grown to midlog phase, harvested $\left(5,000 \times \mathrm{g}, 15 \mathrm{~min}, 4^{\circ} \mathrm{C}\right)$, washed twice in Tris - EDTA (1M, pH 7.0), resuspended in $1 \mathrm{~mL}$ Tris-EDTA lysozyme (20 $\mathrm{mg} / \mathrm{mL}$ ) and incubated for $2 \mathrm{~h}$ at $37^{\circ} \mathrm{C}$. Upon addition of $0,1 \mathrm{mg} / \mathrm{mL}$ of proteinase $\mathrm{K}$ and incubation for $1 \mathrm{~h}$ at $56^{\circ} \mathrm{C}, 1.5 \%$ sarcozyl was added to achieve a final concentration of $15 \mathrm{mM}$ and incubated at $65^{\circ} \mathrm{C}$ for $5 \mathrm{~min}$. Finally, a phenolchloroform extraction was made. After electrophoresis on $0.7 \%$ agarose (Invitrogen Corporation, USA), gel was stained with ethidium bromide and DNA was visualized under UV light.

\section{e) Amplification and restriction analysis of rpoB gene region}

Primers

rрoB1

(5'ATTGACCACTTGGGTAACCGTCG-3'), rpoB10
(5`ATCGATCACTTAGGCAATCGTCG-3') and rpoB2 (5'ACGATCACGGGTCAAACCACC-3') were used to amplify a region of $294 \mathrm{bp}$ of the rpoB gene from reference strains and $L A B$ isolates [11]. Amplifications were performed by touchdown PCR [11]. PCR products were visualized on a $1.5 \%$ agarose gel in the presence of a $100 \mathrm{bp}$ ladder (Productos Bio-Lógicos, Argentina). Amplicons were used for restriction analysis with the enzymes Hinfl (New England BioLabs Inc., USA), and Acil (Fermentas International Inc., Canada). Digestion products were detected by electrophoresis on $3 \%$ agarose gel with ethidium bromide using a $50 \mathrm{bp}$ ladder marker as size standard (Productos BioLógicos, Argentina).

\section{f) Cloning and sequencing of rpoB fragments} $r p o B$ gene region of $L A B$ isolates presumptively identified as belonging to $O$. oeni was cloned in a commercial vector pGEM-T Easy Vector System (Promega Corp., Wisconsin, USA). Clones were sequenced with universal primers $T 7$ and SP6 by means of a $3730 \mathrm{XL}$ DNA automatic sequencer (Applied Biosystems, California, USA). A multiple sequence alignment using the Clustal $X$ Program [12] was performed with the obtained sequences.

\section{g) Malolactic enzyme gene amplification (mle gene)}

A 1025 bp region of malolactic enzyme gene (mle gene) from 0 . oeni was amplified following the methodology developed by Zapparoli et al. [13]. The PCR species-specific reaction was performed with primers On1 (5'TAATGTGGTTCTTGAGGAGAAAAT-3') and On2 (5'-ATCATCGTCAAACAAGAGGCCTT-3'); primers On3 (5'-AATATTCAATACGAATCACG-3') and On4 (5'-GATTCCAGTTCCTTGAATA-3') were employed with the On1/On2 amplified products as targets in nested PCR to confirm the identities of the DNA fragments [13]. The PCR reaction mix and amplification conditions were the same that described by Zapparoli et al. [13] except for annealing temperature in the first reaction which was settled on $53{ }^{\circ} \mathrm{C}$. DNA fragments were separated by electrophoresis on a $1.5 \%$ agarose gel.

\begin{abstract}
h) Sequencing of 16S-rRNA gene 16S-pA (5'-AGAGTTTGATCCTGGCTCAG-3') and 16S-pH (5'-AAGGAGGTGATCCAGCCGCA-3') primers were used to amplify 16S-rDNA [29]. DNA amplification was carried out according to Rodas et al. [14]. PCR products obtained were sequenced with primers 16S-pA and 16S-pH. Multiple alignments of nucleotide sequences were performed by Clustal X Program [12].
\end{abstract}

\section{i) Phenotypic and genotypic typing}


Two random primers were used separately in this study for genotypic typing, M13 [15] and Coc [16]. Amplifications were performed as previously described [17] and PCR products were submitted to electrophoresis for $2 \mathrm{~h}$ at $60 \mathrm{~V}$ on $1.5 \%(\mathrm{w} / \mathrm{v})$ agarose gel. API $50 \mathrm{CH}$ galleries (API System, BioMerieux, France) were used for further characterization of 0 . oeni identified isolates and the reference strain.

\section{j) Cluster analysis}

High-performance photographs of RAPD-PCR gels were obtained by Kodak Electrophoresis Documentation and Analysis System 120, and analyzed by Kodak Digital Science V.3.0.2 (Kodak, Connecticut, USA). From the two RAPD-PCR profiles and API $50 \mathrm{CH}$ results, a unique dendrogram was obtained by pair-wise comparison of profiles. Pattern evaluation was made by calculation of genetic similarity index, using simple matching coefficient [18]. Unweighted Pair Group Method using Arithmetic Averages (UPGMA) cluster analysis was carried out by using PAUP* $4.0 \mathrm{~b} 10$ (Sinauer Associates, MS, USA).

\section{k) Ethanol tolerance of 0 . oeni isolates}

To study ethanol tolerance, $30 \mathrm{~mL}$ of MRS-TJ broth supplemented with ethanol to final concentrations of $6 \%, 10 \%$ and $14 \%(\mathrm{v} / \mathrm{v})$ were inoculated with $1 \times 10^{6}$ $\mathrm{cfu} / \mathrm{mL}$ of each 0 . oeni isolate. Samples were grown at $28{ }^{\circ} \mathrm{C}$ without shaking. Bacterial growth was followed by Optical Density at $600 \mathrm{~nm}\left(\mathrm{OD}_{600}\right)$ until a plateau was reached.

\section{I) Malolactic activity (MLA)}

To evaluate malolactic activity, $30 \mathrm{~mL}$ of modified MRS-TJ broth ( $\mathrm{pH} 4.8$ ) supplemented with $6.5 \mathrm{~g} / \mathrm{L}$ of L-malic acid and 10 or $14 \%(v / v)$ of ethanol (final concentration) were inoculated with $1 \times 10^{6} \mathrm{cfu} / \mathrm{mL}$ of each $\mathrm{O}$. oeni isolate and incubated at $28^{\circ} \mathrm{C}$ without shaking. To follow the process, $\mathrm{OD}_{600}$ and the remaining L-malic acid (L-Malic Acid MegaQuant ${ }^{\mathrm{TM}}$ Format enzymatic kit, Ireland) were measured. A calibration curve with L-malic concentration between 0 and $7 \mathrm{~g} / \mathrm{L}$ was used.

\section{RESULTS \\ Identification of 0 . oeni isolates}

In order to select LAB isolates, the different bacterial colonies obtained from Pinot noir wine samples were tested by Gram stain and catalase activity. Thirty one and fifty one $L A B$ isolates were obtained from the NF and GF, respectively.

The rpoB gene fragment digestion was used for presumptive identification of $O$. oeni isolates. From Hinfl digestion profiles of rpoB gene, it could be inferred the presence of Lactobacillus spp, Leuconostoc mesenteroides, Pediococcus spp and Oenococcus oeni (Fig. 1a). Three isolates from guided vinification shared the same profile that 0 . oeni ATCC 27310 (Fig. 1a). These presumptive 0. oeni indigenous isolates were named: UNQOe 31, UNQOe 71 and UNQOe 73. No one isolate from natural vinification shared Hinfl digestion profile with O. oeni ATCC 27310. Further digestion with Acil enzyme was suitable to assure differences among some isolates with similar Hinfl profiles [11]. UNQOe 31, UNQOe 71 and UNQOe 73 and O. oeni ATCC 27310 showed the same Acil digestion profile (Fig. 1b).

The belonging of isolates to 0 . oeni species was confirmed by species-specific and nested PCR as shown in Fig. (2).

Finally, sequences of rpoB gene fragment and $16 \mathrm{~S}$ $r R N A$ gene were obtained from the all indigenous 0 . oeni isolates and the reference strain. Similarity values obtained were higher than $99 \%$ for rpoB gene fragment and higher than $98 \%$ for $16 \mathrm{~S}$ rRNA gene.

\section{Typing of 0 . oeni isolates}

A polyphasic approach was carried out to explore the diversity of indigenous 0 . oeni. In this context, sugar fermentation patterns by API System and RAPD-PCR profiles using primers $\mathrm{Coc}$ and M13 were obtained. Carbohydrate fermentation behaviour showed a high heterogeneity among isolates, and between them and 0 . oeni ATCC 27310 strain. All indigenous 0 . oeni isolates were able to use pentoses like L-arabinose, D-xylose and D-ribose, whereas the reference strain has not shown capability to ferment these substrates. UNQOe 31 was the only one isolate able to use rhamnose as well as mannose. This last hexose was also used by 0 . oeni reference strain. Differences among fermentative profiles of isolates were also observed for disaccharides lactose, sucrose and cellobiose (Fig. 3a).

RAPD-PCR profiles obtained for isolates and reference strain with both $\mathrm{Coc}$ and $\mathrm{M} 13$ primers are shown in Fig. (3b). Higher band complexity was evidenced with $\mathrm{Coc}$ primer, which allowed more discriminatory possibilities. RAPD-PCR analysis leaded consistently to an evident differentiation between autochthonous isolates and reference 0 . oeni strain. On the other hand, differences among indigenous isolates were revealed (Fig. 3b).

The UPGMA dendrogram obtained by combination of above described genotypical and phenotypical data of the 0 . oeni isolates and reference strain is shown in Fig. (3c). Based on an arbitrary distance value of 0.15 , three clusters were segregated, one for the reference strain, one for the isolate UNQOe 31 and the last one for the remaining two isolates.

\section{Technological properties of indigenous 0 . oeni} isolates

Isolates UNQOe 31, UNQOe 71, and UNQOe 73 showed higher capacity of growth than 0 . oeni ATCC 27310 reference strain, when they were 
cultured at $28^{\circ} \mathrm{C}$ in a nutritive free ethanol medium (MRS-TJ broth) (data not shown).

0 . oeni isolates were grown against rising ethanol concentrations to evaluate the influence of this alcohol on bacterial growth. Fig. (4a) shows the inhibitory effect of ethanol concentrations ranging from 6 to $14 \%(\mathrm{v} / \mathrm{v})$, after $36 \mathrm{~h}$ of growing. However, after $220 \mathrm{~h}$, cell mass of isolates 31,71 and 73 growing in MRS-TJ supplemented with 6 and $10 \%$ of ethanol reached similar values to those obtained under optimal conditions (without ethanol), (Fig. 4b). Increase in ethanol content up to $14 \%$ (v/v) (typical ethanol content in Pinot noir Patagonian wines), produced a partial decrease in the cell mass (Fig. 4b). Fig. (5) shows the different behaviors among isolates growing in MRS-TJ plus 14\% (v/v) ethanol. It can be seen a strong inhibitory effect of ethanol on UNQOe 31 isolate at the end of its growth phase.

Malolactic activity of the three isolates was assayed by measuring the L-malic acid consumption on MRS-TJ broth plus $14 \%(\mathrm{v} / \mathrm{v})$ of ethanol. The three 0 . oeni isolates were able to exhaust the L-malic acid content $(6.5 \mathrm{~g} / \mathrm{L})$ in the media after $84 \mathrm{~h}$ of incubation (Fig. 6). A clear correlation between $\mathrm{OD}_{600}$ and malolactic activity was also found. In order to evaluate if ethanol was able to inhibit the malolactic activity, this assay was also made using $10 \%(v / v)$ of ethanol obtaining the same results. In both cases the three 0 . oeni isolates were able to consume more than $90 \%$ of L-malic acid when the $\mathrm{OD}_{600}$ reach values of $0.4-0.5$ (data not shown).

\section{DISCUSSION}

The use of $L A B$ selected from the indigenous biota of a winegrowing region as malolactic starters is an alternative to commercial LAB strains [19]. This approach is based on the assumption that a better adjustment of the strains to a given ecological environment might improve the quality of wine maintaining the typical regional peculiarities [20]. The grape variety Pinot noir has shown good adaptation to geographical and climatic conditions of Argentinean North Patagonia. The malic acid concentration in these wines can fluctuate between 2.2 to $4.5 \mathrm{~g} / \mathrm{L}$ [9].

Recently Solieri et al. [21] have proposed a selection plan for new 0 . oeni starters that includes four phases: i- constitution of strains collection, ii- 0 . oeni population genotyping, iii- selection of different 0 . oeni genotypes on the basis of their technological properties, and iv- MLF (Malolactic fermentation ) test in winery.

In the present work, three isolates from GF have been found belonging to $O$. oeni species from all LAB isolates analyzed (GF and NF). The fact that no one isolate of $O$. oeni has been found in NF could be related to winery practices as higher sulfiting in NF than in GF, at the crushing step. It is known that survival and growth of 0 . oeni isolates in wine depends on the ability to use different energy sources as well as to tolerate a very harsh environment (low $\mathrm{pH}$, high ethanol content, high $\mathrm{SO}_{2}$ concentration, low temperature, nutrient depletion) [22, 23]. Additionally, over growth of other faster growing $L A B$ species during the enrichment step could explain the limited number of $O$. oeni isolated.

Isolates UNQOe 31, 71 and 73 were identified using molecular tools that have been already adapted and successfully used $[11,13,14]$.

RAPD-PCR has been used as a powerful tool to discriminate the genetic diversity among 0 . oeni isolates from the same region [24, 25]. In this work, typing was made using a polyphasic approach that included RAPD-PCR analysis and carbohydrate fermentation behavior, which led to a robust differentiation at the strain level that is important to avoid a redundant strain collection. All 0 . oeni isolates obtained showed differences in genotypic diversity as well as in their carbohydrate fermentation behavior, in good correlation with other studies [21, 25].

The ability of O.oeni isolates to grow and undergo malolactic activity in presence of different ethanol concentrations was tested, since alcohol can be a limiting factor for $L A B$ growth, as well as for the onset MLF [19]. Alcohol tolerance did not show significant differences among three 0 . oeni isolates when ethanol concentrations were lower than $10 \%$. However, higher amount of ethanol (14\%) showed a differential behavior between UNQOe 31 and the other two isolates, UNQOe 71 and UNQOe 73. A clear correlation was found between the different clusters obtained (Fig. 3c) and their ethanol tolerance.

All 0 . oeni isolates evidenced a strong malolactic activity at the different ethanol concentrations assayed, indicating that ethanol just affects the growing parameters of bacteria, but not the malolactic activity.

This study is the first report of 0 . oeni species isolated from Pinot noir wine in Argentinean Patagonia region. The three 0 . oeni isolates obtained were well characterized showing phenotypic and genotypic differences; they also evidenced adequate technological properties which suggest that all UNQ isolates might be used as malolactic starters in winemaking. Further studies, including simulated microvinifications, are necessary to accomplish a more integrated approach.

\section{ACKNOWLEDGEMENTS}

This work was supported by grants from Universidad Nacional del Comahue $\mathrm{N}^{\circ}$ 04/l146, Universidad Nacional de Quilmes (Programa Microbiología Molecular Básica y Aplicaciones Biotecnológicas № 
53/1003), Comisión de Investigaciones Científicas de la Provincia de Buenos Aires (CIC-PBA) and ANPCyT (PICTO UNQ 2006 № 36474). BM Bravo Ferrada and Y Curilén are recipient of fellowships from Consejo Nacional de Investigaciones Científicas y Técnicas (CONICET) and ANPCYT, respectively. Dr. L. Semorile is member of the Research Career of CICPBA.

\section{REFERENCES}

[1] Bon E., Delaherche A.,Bilhere E., De Daruvar A. and Lonvaud-Funel A. (2009) Applied Microbiology and Biotechnology 75, 20792090.

[2] Lonvaud-Funel A. (1999) Antonie van Leeuwenhoek 76, 317-331.

[3] Maicas S. (2001) Applied Microbiology and Biotechnology 56, 35-39.

[4] Wibowo D., Fleet G.H., Lee T.H. and Eschenbruch R.E. (1988) Journal of Applied Bacteriology 64, 421-428.

[5] Coucheney F., Desroche N., Bou M., TourdotMarèchal R., Dulau L. and Guzzo J. (2005) International Journal of Food Microbiology 105, 463-470.

[6] De las Rivas B., Marcobal A. and Muñoz R. (2004) Applied and Environmental Microbiology 70, 7210-7219.

[7] Delaherche A., Bon E., Dupé A., Lucas M., Arveiler B., De Daruvar A. and Lonvaud-Funel A. (2006) Applied Genetics and Molecular Biology 73, 394-403.

[8] Marcobal A.M., Sela D.A., Wolf Y.I., Makarova K.S., and Mills D.A. (2008) Journal of Bacteriology 190, 564-570.

[9] Le Guillou B. (2000) La Vigne 116, 112-113.

[10] Llorente A. and Casazza M. (2005) El vino y su industria 40, 7-13.

[11] Claisse O., Renouf V. and Lonvaud-Funel A. (2007) Journal of Microbiological Methods 69, 387-390.

[12] Thompson J.D., Higgins D.G. and Gibson T.J. (1994) Nucleic Acids Research 22, 4673-4680.

[13] Zapparoli G., Torriani S., Pesente P. and Dellaglio F. (1998) Lettters in Applied Microbiology 27, 243-246.

[14] Rodas A.M., Ferrer S. and Pardo I. (2003) Systematic and Applied Microbiology 26, 412422.

[15] Stendid J., Karlsson J.O., Hogberg N. (1994) Mycology Research 98, 57-63.

[16] Cocconcelli P.S., Porro D., Galandini S. and Senini L. (1995) Letters in Applied Microbiology 21, 376-379.

[17] Delfederico L., Hollmann A., Martínez M., Iglesias N.G., De Antoni G. and Semorile L. (2006) Journal of Dairy Research 73, 20-27.

[18] Apostol B.L., Black W.C. IV, Miller B.R., Reiter P. and Beaty B.J. (1993) Theoretical Applied Genetics 86, 991-1000.
[19] Masquè C. and Bordons A. (1996) Journal of Wine Research 7, 91-101.

[20] Izquierdo P.M., García E., Martínez J. and Chacón J.L. (2004) Journal of Grapevine Research 43, 149-153.

[21] Solieri L., Genova F., De Paola M. and Giudici P. (2010) Journal of Applied Microbiology 108, 285-298.

[22] Saguir F.M. and Manca de Nadra M.C. (2002) Journal of Applied Microbiology 93, 295-301.

[23] Zapparoli G., Moser M., Dellaglio F., TourdotMaréchal R. and Guzzo J. (2004) Letters in Applied Microbiology 39, 48-54.

[24] Bartowsky E., McCarthy J. and Henschke P.A. (2003) Australian Journal of Grape and Wine research 9, 122-126.

[25] Izquierdo P.M., Ruiz P., Seseña S. and Palop M.L. (2009) Journal of Bioscience and Bioengineering 108, 220-224. 

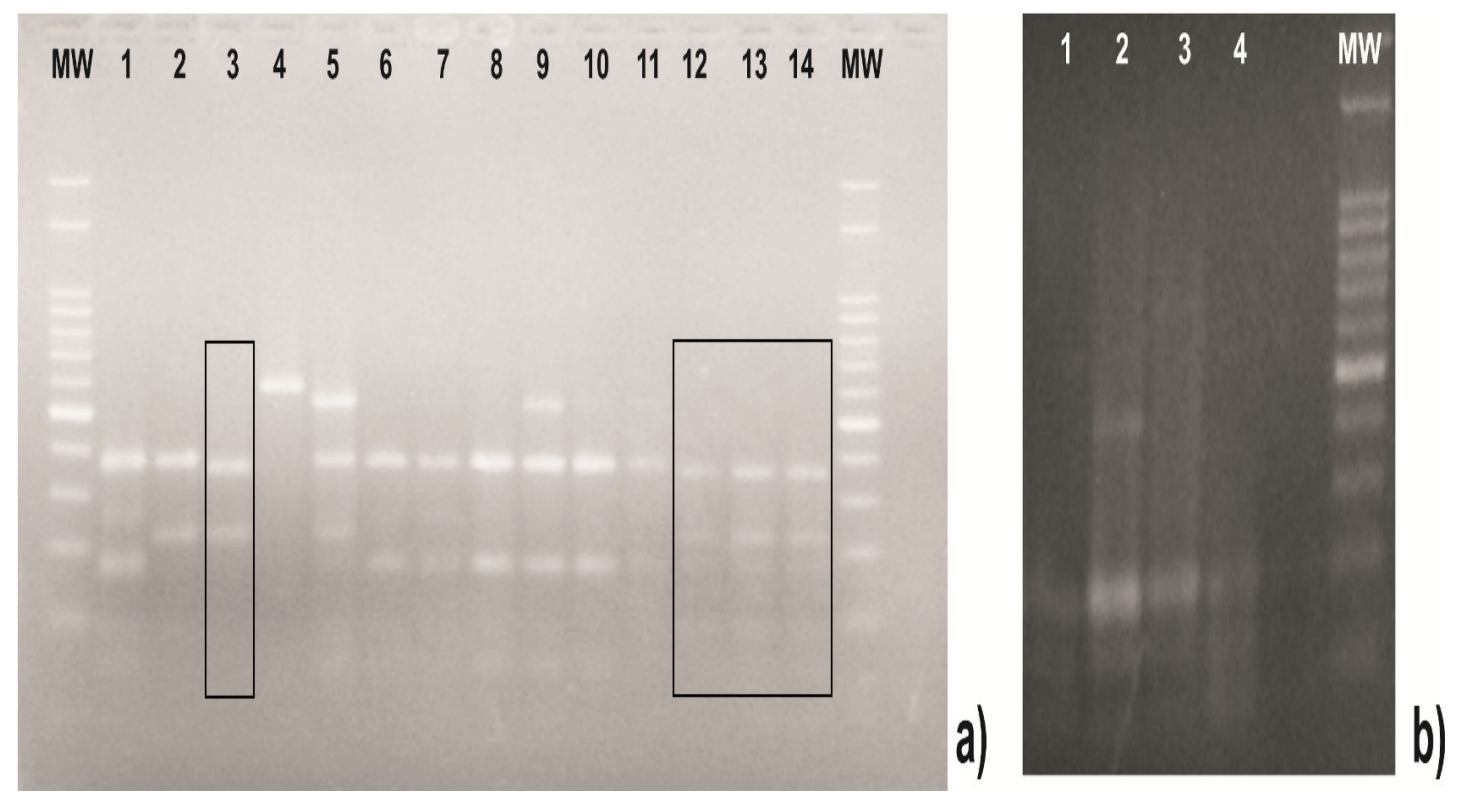

Fig. 1a- Differentiation of LAB species by rpoB PCR-RFLP using Hinfl.

Lanes: 1. L. plantarum DSM 20174 , 2. L. mali ATCC 27304, 3. O. oeni ATCC 27310, 4. Leuconostoc mesenteroides ATCC 23386, 5. Pediococcus parvulus ATCC 19371, 6. UNQ 13, 7. UNQ 65, 8. UNQ 158, 9. UNQ 147, 10. UNQ 140, 11. UNQ 146, 12. UNQOe 73, 13. UNQOe 31, 14. UNQOe 71. MW. Molecular weight marker (50 bp Productos Bio-Lógicos).

Fig. 1b- Acil digestion of 0 . oeni isolates and reference strain.

Lanes: 1. O. oeni ATCC 27310, 2. UNQOe 31, 3. UNQOe 71, 4 UNQOe 73, MW. Molecular weight marker (50 bp Productos Bio-Lógicos).

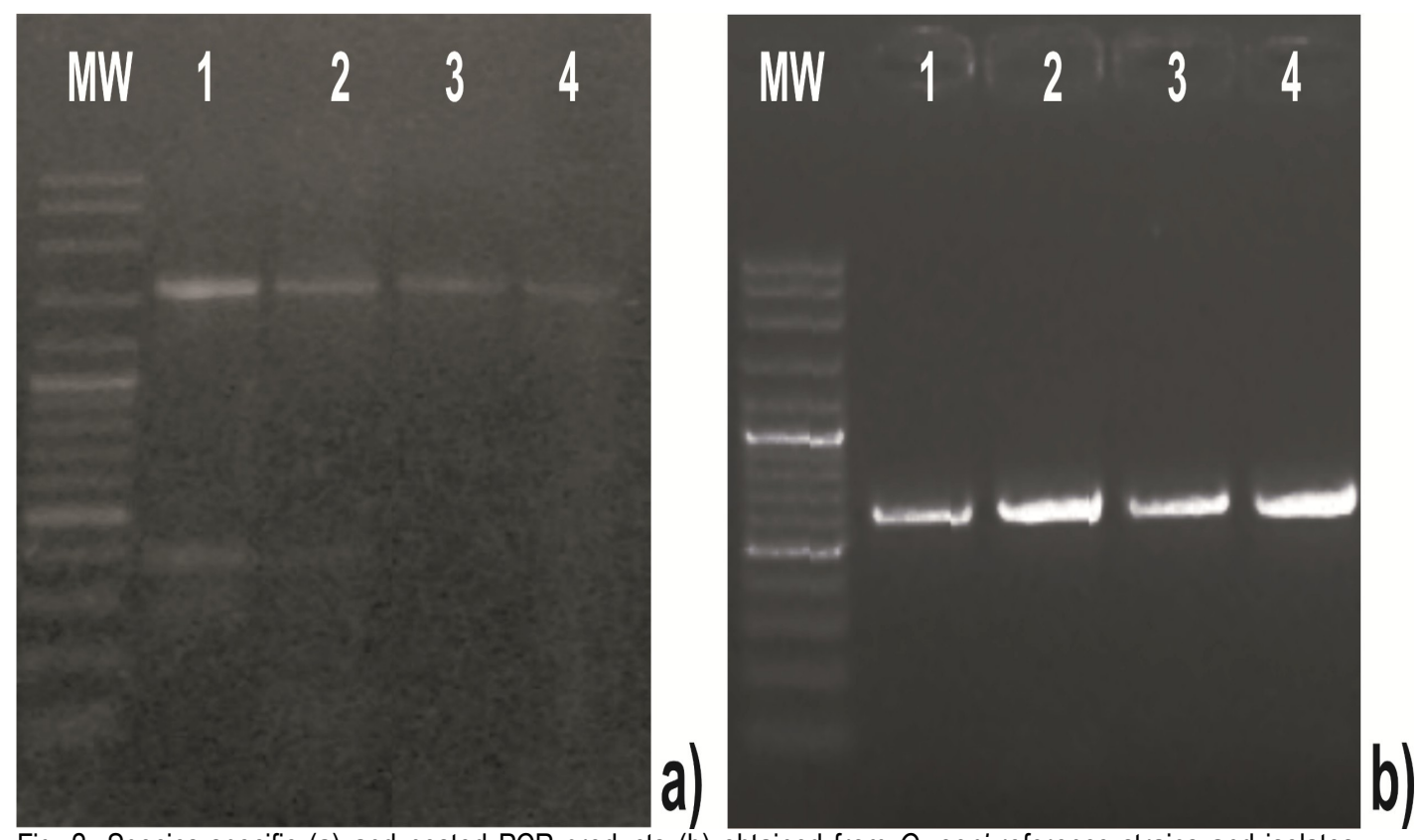

Fig. 2- Species-specific (a) and nested PCR products (b) obtained from 0 . oeni reference strains and isolates. Lanes: MW. Molecular weight marker (100 bp Genbiotech ladder), 1. O. oeni ATCC 27310, 2. UNQOe 31, 3. UNQOe 71, 4. UNQOe 73. 


\begin{tabular}{|c|c|c|c|c|}
\hline & UNQOC 31 & UNQOC 71 & UNQOC 73 & Control \\
\hline D-arabinose & + & + & + & - \\
\hline Ribose & + & + & + & - \\
\hline D-Xvose & + & + & + & - \\
\hline Metil- -xvlopvranoside & + & + & + & - \\
\hline Manose & + & . & - & + \\
\hline L-thamnos $\theta$ & + & - & - & - \\
\hline Melvl- D-Glucubvranoside & + & + & + & - \\
\hline D-Celobiose & + & . & + & + \\
\hline D Lactbse & + & & + & + \\
\hline D-Saccharose & + & - & + & + \\
\hline K2-Ceto Gluconate & - & + & + & - \\
\hline K5-Ceb Gluconate & + & + & + & . \\
\hline
\end{tabular}

$\begin{array}{llll}71 & 73 & 31 & \text { Control }\end{array}$

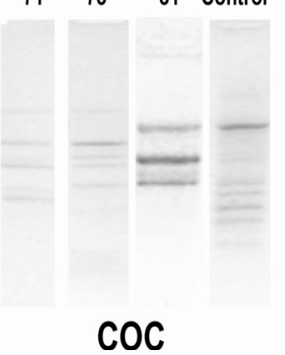

A

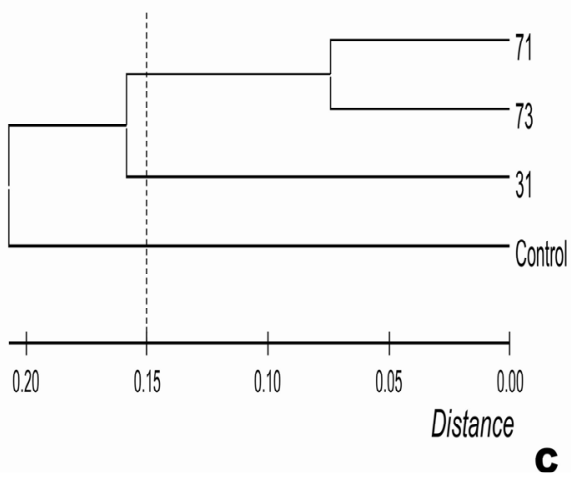

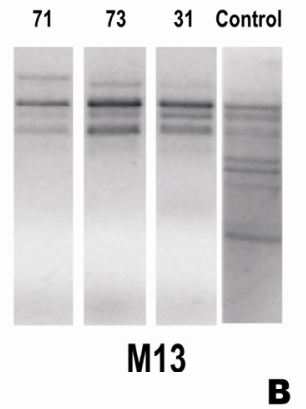

B

Fig. 3-Sugar fermentation patterns of 0 . oeni isolates and reference strain

a) RAPD-PCR profiles obtained with Coc and M13 primers and, b) combined dendrogram obtained from sugar fermentation and RAPD-PCR patterns. c) Control: O. oeni ATCC 27310 strain.
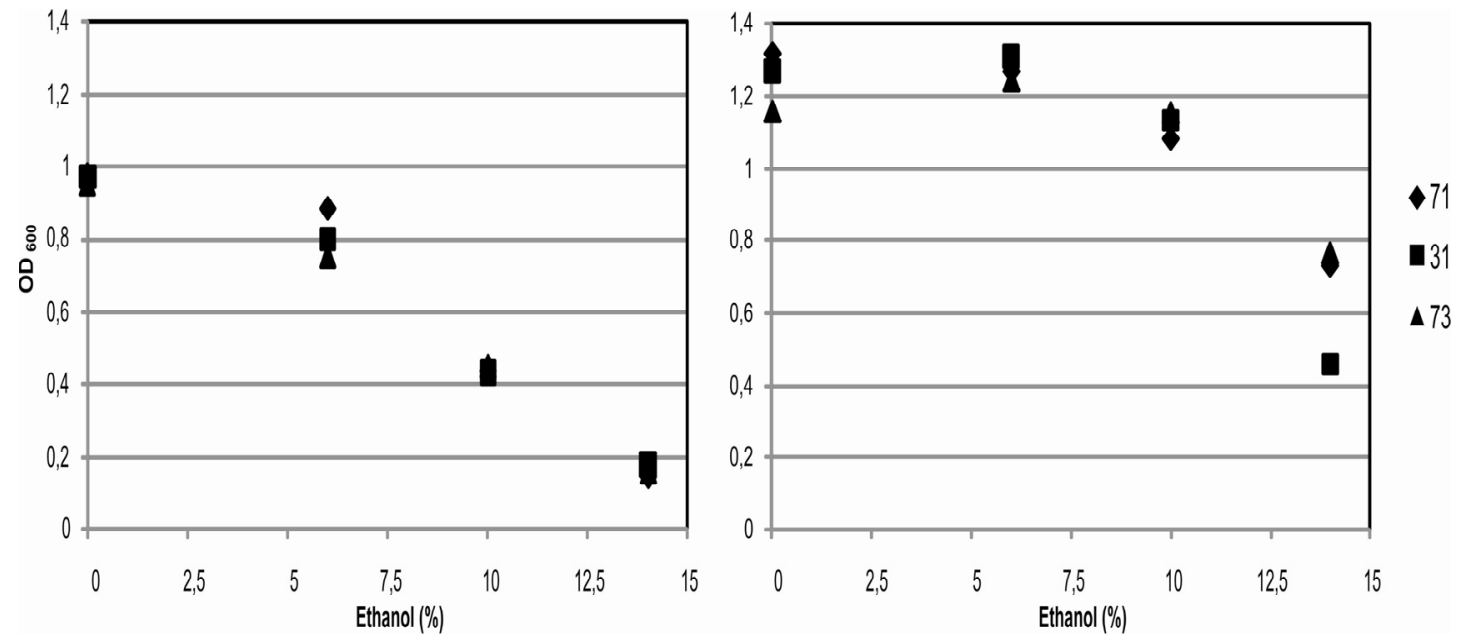

Fig. 4- $\mathrm{OD}_{600}$ of $\mathrm{O}$. oeni isolates after incubation of $36 \mathrm{~h}(\mathrm{a})$ or $220 \mathrm{~h}(\mathrm{~b})$ at $28^{\circ} \mathrm{C}$ in MRS-TJ and $6.5 \mathrm{~g} / \mathrm{L}$ of L-malic acid as a function of ethanol concentration. Each value is the mean of triplicate experiments. In all cases the SD was lower than $10 \%$ of the mean value. 


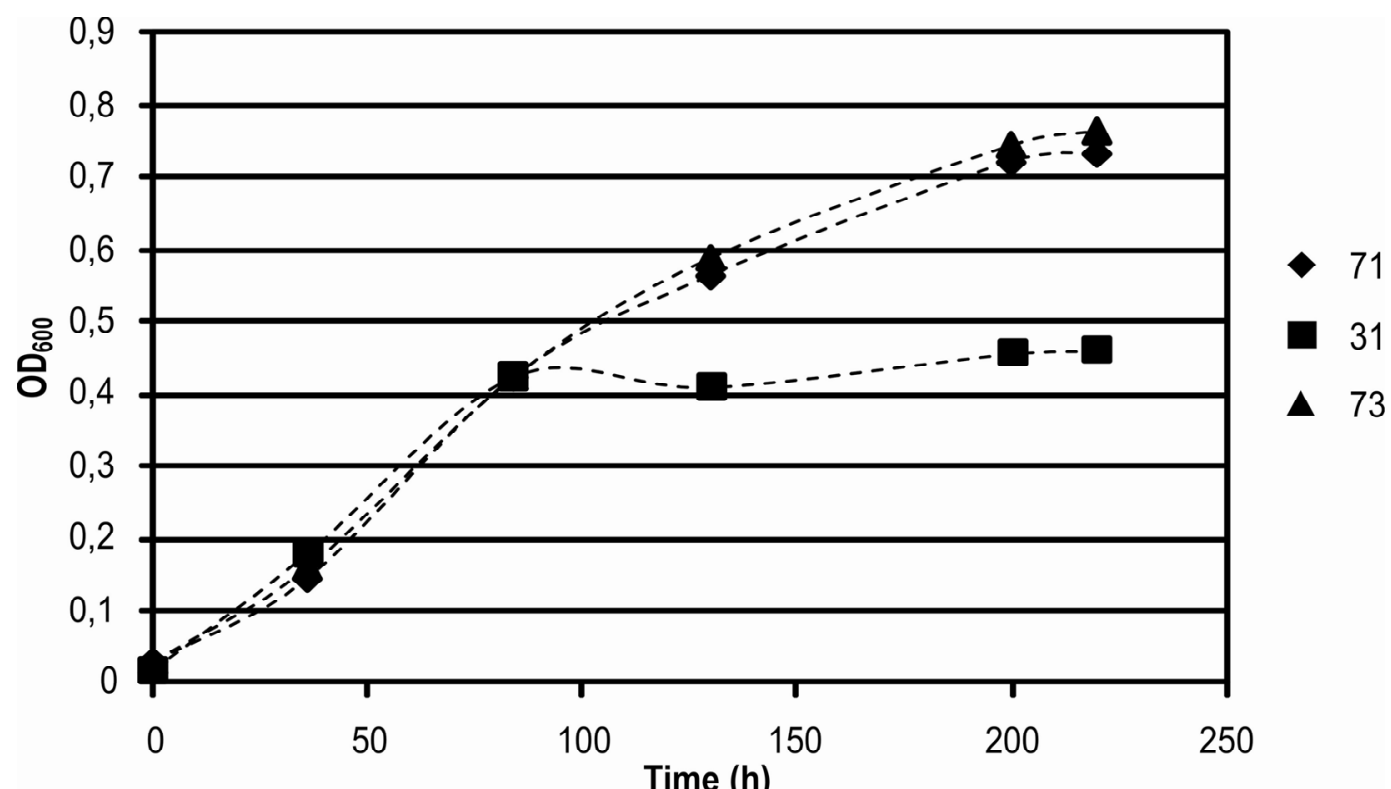

Fig. 5- Effect of $14 \%$ ethanol on 0 . oeni isolates growth as a function of time. Cells were incubated in MRS-TJ at $28{ }^{\circ} \mathrm{C}$. Each value is the mean of triplicate experiments. In all cases the SD was lower than $10 \%$ of the mean value.

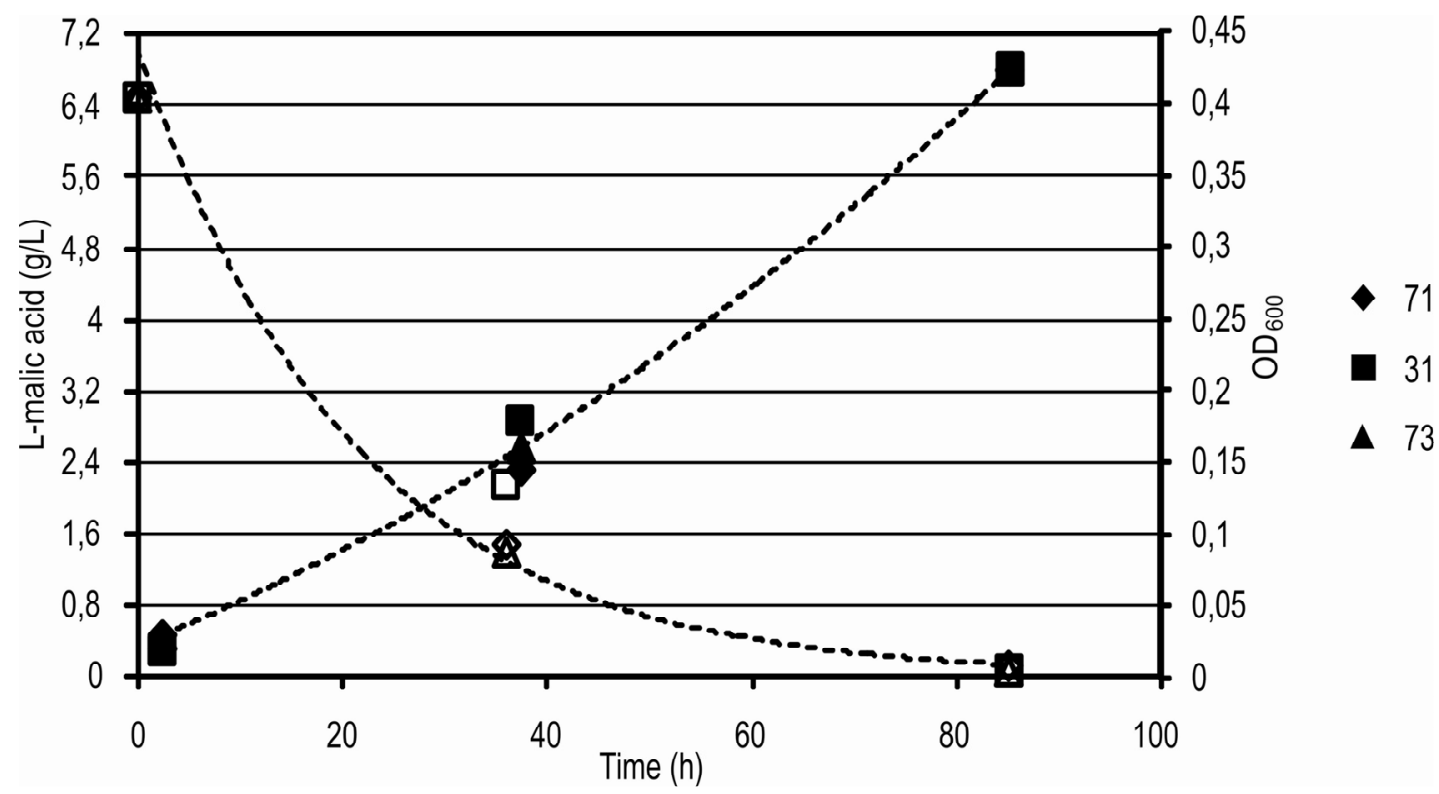

Fig. 6-OD 600 (filled symbols) and L-malic acid consumption (empty symbols) of 0 . oeni isolates as a function of time. Each value is the mean of triplicate experiments 